POLITYKA ENERGETYCZNA - ENERGY POLICY JOURNAL

$2021 \downarrow$ Volume $24 \uparrow$ Issue $4 \uparrow 121-138$

DOI: $10.33223 / \mathrm{epj} / 144861$

\title{
Conceptual provisions of the transformation of the national energy system of Ukraine in the context of the European Green Deal
}

ABSTRACT: This article is aimed at the scientific and methodological substantiation of conceptual provisions for the transformation of the national energy system of Ukraine through the formation of eco-energy clusters. The article analyses international reports on the development of green energy in different countries. An analysis of the dynamics of energy consumption in Ukraine on the basis of renewable sources for 2007-2019 is performed. An algorithm for making a management decision on the transition to renewable energy sources is proposed. In order to transform the national energy system, a conceptual approach to the formation of an eco-energy cluster as an element of innovation infrastructure based on smart specialization is substantiated. It is proven that this structure should be in the form of the partnership of energy companies, business structures, research institutions,

$\triangle$ Corresponding Author: Nataliia Trushkina; e-mail: 9mriya@gmail.com

1 Department of Regulatory Policy and Entrepreneurship Development, Institute of Industrial Economics of National Academy of Science of Ukraine, Ukraine; ORCID iD: 0000-0002-6741-7738; e-mail: 9mriya@gmail.com

2 Vice-Rector for International Relations, International Humanitarian University, Ukraine; ORCID iD: 0000-0002-7635-0037; e-mail: alireza2@ukr.net

3 Department of International Law and Comparative Law, International Humanitarian University, Ukraine; ORCID iD: 0000-0002-2807-7320; e-mail: A.pahlevanzade@ukr.net

4 Department of Management and Innovations, Odessa I.I. Mechnikov National University, Ukraine; ORCID iD: 0000-0001-6400-7840; e-mail: evgenmaslennikov@onu.edu.ua

2021. The Author(s). This is an open-access article distributed under the terms of the Creative Commons Attribution-ShareAlike International License (CC BY-SA 4.0, http://creativecommons.org/licenses/by-sa/4.0/), which permits use, distribution, and reproduction in any medium, provided that the Article is properly cited. 
higher education institutions, institutions of logistics, energy and innovation infrastructure, and government agencies. This, in turn, will provide a synergistic effect (economic, environmental, social) by improving a number of existing legislations on alternative energy sources, which would increase the economic efficiency of their production, such as: the development of investment projects to attract additional investments in this industry; state guarantees to producers of "clean" energy for its purchase at fixed tariffs; ensuring the level of energy security of Ukraine through the modernization of the network of existing power plants to increase the level of their reliability and uninterrupted operation; the reduction of greenhouse gas emissions from the combustion of traditional fuels.

KEYWORDS: state energy policy, national energy system, renewable energy, eco-energy cluster, green technologies, green economics

\section{Introduction and literature review}

At present, issues of the transformation of the energy sector in European countries in the context of green economics are especially relevant. This is due to the need to implement the European Green Course, which should ensure the growth of the share of the renewable energy sources and the creation of favorable conditions to increase the attractiveness of investment in this area.

In addition, it is in line with global trends in the development of national energy systems. Thus, according to a survey by Deloitte (2017), most companies have decided to implement more capital-intensive projects to regulate energy use. At the same time, $34 \%$ of respondents stated the installation of solar panels and energy production plants at their enterprises and $26 \%$ mentioned the installation of batteries for energy storage and the storage of electricity as potential hedging during peak hours in conditions of rising prices.

According to expert estimates by Ernst \& Young, a renewable energy share rise in the total volume of EU energy from 27 to $35 \%$ by 2021 would increase the number of people employed in solar energy to 175 thousand people. The European Solar Energy Association estimates that the implementation of a proper industrial policy in this area can increase employment in solar generation to 300 thousand people.

However, according to a study published in the journal Nature Energy, only one in ten energy suppliers in the world prefer renewable energy sources over fossil fuels. In Europe, renewable energy has taken a significant market share: in $2019,40 \%$ of British electricity was generated by wind and solar power. However, although we can see the growing "green" energy trend around the world, only $10 \%$ of companies have expanded their production of electricity from renewable sources.

Due to the COVID-19 pandemic, global energy demand decreased by $5 \%$, electricity demand decreased by $2 \%$, carbon emissions from the energy sector decreased by $7 \%$, and investment in energy decreased by $18 \%$, as it was fixed in the World Energy Review of the International Energy Agency (2020). Furthermore, renewable energy sources remained the most resilient to the challenges of the COVID-19 pandemic. 
It is recommended that Ukraine takes into account international best practices, setting a course for the energy balance provision, stimulating economic activity, creating jobs, and increasing energy security. Thus, the use of non-traditional energy sources enables, first of all, the taking of a step towards the country's energy independence.

To solve these problems, it is advisable to create cluster structures, the functioning of which should meet modern challenges related to the intensification of globalization and European integration, smart specialization, the modernization of the national energy system, and the digitalization of organizational and managerial processes.

In view of this, there is a need for further development of theoretical and methodological provisions and the development of scientific and methodological approaches and practical recommendations for the transformation of the energy sector based on the formation of eco-energy clusters in the context of green economics and balanced sustainable development (European classification NUTS 1).

The clusters encompass an array of linked industries and other entities important to competition. These include suppliers of specialized inputs such as components, machinery, and services, and providers of specialized infrastructure, introduced by M. Porter (1998). According to his study about the concentration and interconnected companies, he came to the conclusion that clusters promotes competition and cooperation simultaneously, and this is a big benefit for productivity.

Foreign scientists (Devlin and Bleackley 1988; Swann and Preveser 1996; Feser 1998; Feldman and Audretsch 1999; Dussauge et al. 2000) carry out research on cluster issues, considering the cluster as fundamentally new institutions of the economic system, which appear under the influence of factors of the institutional environment and the development of global competition.

Analysis of scientific sources shows that the problems and prospects of energy policy and the development of renewable energy sources are devoted to a significant number of works by foreign and domestic researchers (including: Terrados et al. 2009; Diekman and Traber 2012; Boyle 2012; Trieb 2013; Fox and Flynn 2014; Yuan et al. 2014; Henning 2015; Donovan 2015; Meier and Vagliasindi 2015; Xavier 2015; Nate et al. 2021).

Despite the thorough developments of scientists, an in-depth study of the development of the energy sector using a cluster approach and finding ways to use renewable energy is needed. The substantiation of conceptual bases is especially a reality in modern conditions of the functioning of an energy complex in the context of constant institutional change and the introduction of the green economics mechanism.

Thus, the aim of the study is to develop the concept to transform the Ukrainian energy system to increase the use of renewable energy sources, based on the cluster approach. The methods utilised to reach this goal are logical judgements, system analysis, rule of argumentation for interconnection the macro-economic level policy and inputs to the energy system from the enterprise partnership. 


\section{Global trends in the development of the energy sector}

The report "Global Trends in Renewable Energy Investment", prepared by the United Nations Environment Program (UNEP) with the assistance of Bloomberg New Energy Finance, noted that solar technologies were the most attractive for investors. Significant growth in solar energy investments around the world demonstrates how the global energy system is changing, and the economic benefits of such changes.

Global investment in solar energy development grew by 18\% in 2018 compared to 2017 and amounted to 160.8 billion US dollars. The total investment in renewable energy production, excluding hydroelectric power plants, was 279.8 billion US dollars. Solar energy accounts for $57 \%$ of this amount. This exceeds the volume of investments in capacities operating on gas and coal, amounting to around 103 billion US dollars.

China has become the leader in investments in renewable energy. This country accounts for more than half of all new solar power plants. Other countries actively using solar panels include Australia, Mexico and Sweden.

However, these successes did not affect all countries. In contrast, some large markets have seen a decline in investment in renewable energy development. In the US, investments fell by $6 \%$ to 40.5 billion US dollars. In Europe, such investments fell $36 \%$ to 40.9 billion dollars US.

In general, globally in the period 2007-2017, projects for the development of renewable energy sources were allocated 2.7 trillion dollars of investment. As a result, the share of electricity generated using wind power, solar panels, waste, geothermal sources, sea waves and small hydroelectric facilities increased significantly from 5.2 to $12.1 \%$.

It should be noted that many industries around the world - from Japanese automakers to Australian farmers - are beginning to feel the effects of the energy crisis in China.

According to Bloomberg, energy supply problems caused particularly by the surge in coal prices are likely to affect China's own economic growth, while the impact of this factor on supply chains could weaken the global economy trying to recover from the effects of the COVID-19 pandemic.

Further power outages and related production cuts will exacerbate global supply chain problems, especially if the production of export goods is affected.

All this looks like another shock in the industrial sector caused by stagflation, not only for China, but for the whole world. The rise in prices around the world is spreading across many industries as a consequence of China's deep involvement in global supply chains.

The PRC government has demanded that local coal companies increase production and is looking for opportunities to purchase energy resources around the world, trying to stabilize the situation. The authorities of the Inner Mongolia region, which is one of China's largest coal producers, ordered 72 local companies to increase their production capacity by 100 million. This increase amounted to $10 \%$ of the region's coal production in 2020 (about 1 billion tons). 
The electricity crisis in China is forcing many factories to suspend or switch to a two-day working week, reducing production. About twenty Chinese provinces are affected by power outages, and electricity consumption rationing has been introduced in sixteen provinces. In Guangdong province, China's largest industrial region, nearly 150 thousand companies have been affected by power problems and many business owners believe that rationing could persist for months.

According to ING analysts, disruptions in the supply of goods from China will persist for a significant part of 2022, which will lead to higher prices for popular goods, a decrease in production and a slower recovery in production. Due to these production disruptions, delivery times are extended by 60 to 90 days. According to experts, the cost of goods from China will grow by $10-12 \%$.

China is actively introducing renewable energy sources (RES) into the energy balance, building more and more wind and solar power plants, applying and exporting modern green technologies. At the same time, it does not refuse to support the coal industry and is in no hurry to develop spot electricity markets.

Experts from the Oxford Institute for Energy Research concluded that the PRC will maintain the stability of its wind and solar energy markets, while gradually, step by step, carrying out structural changes. Therefore, in their opinion, even if investments in hydrocarbons are preserved, the combination of market influence and the transformation of domestic policy will lead to the country's transition to green energy.

In their review of the Chinese approach to renewable energy, they note that this year the Celestial Empire retains the world leadership in introducing new photovoltaic capacities, even though the installation of solar panels has slowed down over the past year and a half. So, in 2018, a total of sixty-six GW of wind and solar capacities were commissioned. The latter occupy a record $44 \mathrm{GW}$ in this volume. In 2019, this figure dropped to $56 \mathrm{GW}$, of which $30 \mathrm{GW}$ is solar energy.

The main reason for the current negative dynamics in Oxford is considered to be the lagging of green tariffs from the market. The rapid decline in the cost of wind and solar energy has led to the formation of an alternating boom-and-bust cycle in the sector. At the same time, the authorities are not very good at adjusting green tariffs to them in order to avoid overheating the market. In 2018, the regulator began to give signals that it could completely abandon such tariffs since the money to subsidize them is running out. After all, the corresponding funds are formed from additional charges for electricity, and the government is not going to increase them. In this case, additional funds may appear there only due to the growth in demand for electricity. In 2020, the authorities focused on this, with very limited and selective approval of projects that can benefit from green tariffs.

However, there are also other factors. The ongoing expansion of coal-fired power plants plays a role in weakening the renewable energy market. Their utilization factor is small, but they are viewed as a necessary guarantee of the security of supply. Also, the slowdown in the growth of renewable capacities is explained by the transition to new regions of implementation and more modern technologies. Since onshore wind turbines and large power plants are more competitive without government support, the regulator directed major subsidies and other bonuses to develop 
distributed solar generation, install photovoltaic panels on rooftops, and stimulate offshore wind energy. Thanks to this, distributed generation provided $30.6 \%$ of new solar capacity last year, and offshore wind turbines added $37.8 \%$ over the year.

The peculiarity of the PRC's energy policy is that it combines market methods and planning elements. In accordance with the latest plan this year, experts emphasize that China abandoned ambitious targets for the renewable energy market and switched to a sustainable development strategy. First of all, the authorities focused on the problem of the insufficient consumption of renewable energy. So, in 2016, the total under-supply of energy produced by wind turbines was $17 \%$, and in some provinces it even reached $40 \%$. Therefore, in 2018, the center obliged the regions to reduce the level of undersupply of renewable energy sources, and then completely obliged them to keep it below 5\%. As a result, in 2019 the indicator for wind energy fell to 4\%, and for solar, it dropped to $2 \%$. In addition, renewable energy compliance certificates and green bonds were introduced to support the market. Thus, Beijing wanted to shift the burden of financial support for the sector from the state onto the shoulders of investors, but at the same time Beijing did not create market conditions for the emergence of new renewable energy projects. This is why green certificates, in particular, have not started to enjoy success, according to Oxford.

According to experts, the expected growth of the global market for green technologies is $6.9 \%$ (this is almost twice the growth rate of the world economics). According to forecasts, the total volume of this market by 2025 may increase to 5.9 trillion EUR (Table 1).

If we analyze the data on the structure of the green technologies market, it can be noted that its two main segments are environmentally friendly production, accumulation and distribution of energy ( 21 and 20\% in 2016 and 2020) and the energy efficiency submarket (26 and 25\% in 2016 and 2020). Sustainable mobility and efficient use are projected to grow by 2025 raw materials and materials (Table 2).

By 2030 , global renewable electricity production is expected to reach $10,770 \mathrm{GW}$ - nearly four times the current production. Rapid and massive roll-out is needed over the next ten years to pave the way for decarbonizing the energy system and electrifying end-use by 2050 . This level of deployment is also strongly recommended in the Thematic Report on Energy System Transformation prepared by IRENA, UNEP and the Economic and Social Commission for Asia and the Pacific for the UN High Level Dialogue on Energy. With their abundance around the world, the use of cost-effective potential renewable energy sources can be expanded. For many countries, this turns a technical and economic challenge into a complex of investment, regulatory and social opportunities.

The priority task is to renew, modernize and expand the infrastructure. Renewing obsolete infrastructure or investing in its expansion is an integral part of the energy transition and a factor contributing to the advancement of modern technologies. Over the next ten years, as the share of renewable energy sources increases, this will become an especially urgent task, requiring system flexibility and modern networks. Infrastructure development should be aligned with long-term plans and reflect broader strategies, including regional market integration.

The required roll-out levels will only be achieved by 2030 if policies are in place to support such technology directions. Deployment policies support the creation of markets, thereby faci- 
TABLE 1. The volume of financing for the development of segments of the global market for green technologies

TABELA 1. Wielkość finansowania rozwoju segmentów globalnego rynku zielonych technologii

\begin{tabular}{|l|c|c|c|c|}
\hline \multirow{2}{*}{ Segments } & \multicolumn{2}{|c|}{$\begin{array}{c}\text { Annual value } \\
\text { [billion EUR] }\end{array}$} & $\begin{array}{c}\text { 2025 to 2016, } \\
\text { times }\end{array}$ & $\begin{array}{c}\text { Average annual } \\
\text { growth rate } \\
\text { in 2016-2025 [\%] }\end{array}$ \\
\cline { 2 - 5 } & 2016 & 2025 & & 6.4 \\
\hline $\begin{array}{l}\text { Environmentally friendly production, accumulation } \\
\text { and distribution of energy (renewable energy sources } \\
\text { (RES)), storage, smart grid }\end{array}$ & 667 & 1,164 & 1.75 & 6.6 \\
\hline Energy efficiency submarket & 837 & 1,491 & 1.8 & 8.1 \\
\hline $\begin{array}{l}\text { Efficient use of raw materials and supplies (including } \\
\text { the production of biological substitutes for fossil raw } \\
\text { materials) }\end{array}$ & 521 & 1,048 & 2.0 & 10.2 \\
\hline $\begin{array}{l}\text { Environmentally sustainable mobility (development of } \\
\text { new transport technologies and biofuel production) }\end{array}$ & 412 & 988 & 2.4 & 7.4 \\
\hline Circular economics & 110 & 210 & 1.9 & 4.6 \\
\hline $\begin{array}{l}\text { Environmentally sustainable water management } \\
\text { (including various aspects of wastewater } \\
\text { management) }\end{array}$ & 667 & 1,001 & 1.5 & 6.9 \\
\hline Total & 3,214 & 5,902 & 1.8 & \\
\hline
\end{tabular}

Source: BMU 2018.

TABLE 2. Share of segments of the global market for green technologies [\%]

TABELA 2. Udział segmentów światowego rynku zielonych technologii [\%]

\begin{tabular}{|l|c|c|}
\hline \multirow{2}{*}{\multicolumn{1}{|c|}{ Segments }} & \multicolumn{2}{c|}{ Years } \\
\cline { 2 - 3 } & 2016 & 2025 \\
\hline Energy efficiency submarket & 26 & 25 \\
\hline Environmentally friendly production, accumulation and distribution of energy & 21 & 20 \\
\hline Efficient use of raw materials and supplies & 16 & 18 \\
\hline Environmentally sustainable mobility & 13 & 17 \\
\hline Environmentally sustainable water management & 21 & 17 \\
\hline Circular economics & 3 & 3 \\
\hline
\end{tabular}

Source: BMU 2018. 
litating scaling, reducing technology costs, and increasing investment levels consistent with the needs of the energy transition. Given that large amounts of budgetary funds are being poured into the economies of countries as part of recovery measures, such a policy will determine the direction of the energy transition and create the preconditions for a significant increase in the private sector investment required until 2050.

By 2050, electricity will be the main energy source, and its share will increase from $21 \%$ of the total final energy consumption in 2018 to over $50 \%$ in 2050 . Industry boundaries are shifting as transport and heating of end-use areas are becoming electrified. This growth is mainly driven by the use of electricity from renewable energy sources instead of fossil fuels in end-use areas. As this shift takes place, the annual growth rate of renewable energy technologies will grow eightfold. Electrifying the global final consumption will also lead to the transformation of a number of industries, primarily the transport sector, in which electric vehicles will account for $80 \%$ of all road vehicles in 2050 .

The annual rate of decline in energy intensity should increase to $2.9 \%$ - almost two and a half times that of the historical trend. With this growth, the energy intensity of the global economy will fall by more than $60 \%$ by 2050 . Energy efficient technologies and measures are turnkey solutions with high scalability potential. Policies and measures to improve energy conservation and energy efficiency will be critical to reducing total final energy consumption from 378 exajoules (EJ) in 2018 to $348 \mathrm{EJ}$ in 2050. Structural and behavioral changes also play an important role, contributing approximately $10 \%$ to efficiency gains.

By 2050 , hydrogen and its derivatives will account for $12 \%$ of final energy consumption. They will play an important role in hard-to-decarbonize, energy-intensive sectors such as steel, chemicals, long-haul transport, shipping and aviation. In addition, hydrogen will help balance supply and demand for renewable electricity and will serve as a long-term seasonal storage facility. By 2050, the required capacity of electrolyzers will reach around 5,000 GW, up from $0.3 \mathrm{GW}$ today. This scale of growth has highlighted the importance of low-carbon hydrogen from the outset. In 2050, two thirds of all hydrogen will be "green", produced using electricity based on renewable sources, and one third will be "blue" from natural gas with carbon capture and storage (CCS).

Bioenergy in 2050 will account for $18 \%$ of total final energy consumption. Sustainable production and use of biomass needs to be increased across all segments of the grid. In some sectors, biomass plays an important role - in particular as a feedstock and fuel in the chemical industry, as well as a fuel in the aviation industry. In other areas, it helps solve problems that cannot be completely eliminated by other means, for example, replacing natural gas with biomethane in buildings that cannot be upgraded. In addition, in the power sector and a range of industries, biomass combined with CCS (BECCS) will provide the negative emissions required to achieve the zero emissions target.

Residual use of fossil fuels and some industrial processes may require $\mathrm{CCS}$ and $\mathrm{CO}_{2}$ removal technologies and measures for decarbonization. In the $1.5^{\circ} \mathrm{C}$ scenario, some emissions from the residual use of fossil fuels and some industrial processes will remain in 2050. Therefore, the remaining $\mathrm{CO}_{2}$ will need to be captured and removed. $\mathrm{CCS}$ applications are mainly limited to 
$\mathrm{CO}_{2}$ emissions associated with processes in the cement industry, metallurgy and blue hydrogen production. The process of $\mathrm{CO}_{2}$ removal includes conservation measures such as reforestation and BECCS, direct carbon capture and storage, and other techniques that are still experimental.

\section{Analytical assessment of the current state of the national energy system in Ukraine}

As international practice shows, in recent years, the share of renewable energy in most developed countries has been increasing. The global trends in increasing the capacity of renewable energy have also affected the structure of the energy sector of Ukraine (Serdyuk and Trushkina 2017a, 2017b, 2017c). Wind and solar energy and hydropower are the most often used alternative energy sources, accounting for almost $99 \%$ of all energy produced from renewable sources. Hydropower accounts for $8 \%$ of the country's all-energy energy balance.

The total supply of energy from renewable sources in 2007-2020 increased by $138.5 \%$, and its share in the total supply of primary energy increased from 1.7 to $6.6 \%$. This was due to a 198.5-times increase in the supply of wind and solar energy - and 2.8 times in the case of biofuels and waste (Table 3 ).

The annual report Climate Scope 2019, prepared by Bloomberg New Energy Finance, states that Ukraine has raised fifty-five positions in the ranking of the attractiveness of developing countries in terms of investment in renewable energy, and ranked eighth (in $2018-63$ place). The reasons for this growth are reforms in the energy sector, attractive preferential tariffs, and taxation.

In conformity with the National Renewable Energy Action Plan in 2035, the share of "green" energy in the total primary supply should be $25 \%$. That is, there should be a so-called "energy transition" on the principles of sustainable development from fossil fuels to renewables while stimulating a significant increase in energy-saving resources.

In Ukraine, there are the following mechanisms to support the issues of renewable electricity: "green" tariff; levy benefits; use of the electric network is advisable. Stimulating production with a "green" tariff applies to almost all renewable energy sources (except for electricity generated by large hydropower plants).

Thus, Ukraine is the most attractive European market for renewable energy, which in the future may become a "driver of development" of the national economics. 
TABLE 3. Dynamics of energy consumption based on renewable sources in the structure of the energy balance of Ukraine [thousand tons of oil equivalent]

TABELA 3. Dynamika zużycia energii w oparciu o źródła odnawialne w strukturze bilansu energetycznego Ukrainy [tys. toe]

\begin{tabular}{|c|c|c|c|c|}
\hline \multirow{2}{*}{ Years } & \multirow{2}{*}{ Total volume } & \multicolumn{3}{|c|}{ including } \\
\cline { 3 - 5 } & & Hydropower & Biofuel energy and waste & Wind and solar energy \\
\hline 2007 & 2,384 & 872 & 1,508 & 4 \\
\hline 2008 & 2,604 & 990 & 1,610 & 4 \\
\hline 2009 & 2,463 & 1,026 & 1,433 & 4 \\
\hline 2010 & 2,611 & 1,131 & 1,476 & 4 \\
\hline 2011 & 2,514 & 941 & 1,563 & 10 \\
\hline 2012 & 2,476 & 901 & 1,522 & 104 \\
\hline 2013 & 3,166 & 1,187 & 1,875 & 134 \\
\hline 2014 & 2,797 & 729 & 1,934 & 134 \\
\hline 2015 & 2,700 & 464 & 2,102 & 124 \\
\hline 2016 & 3,616 & 660 & 2,832 & 149 \\
\hline 2017 & 3,907 & 769 & 2,989 & 197 \\
\hline 2018 & 4,289 & 897 & 3,195 & 426 \\
\hline 2019 & 4,348 & 560 & 3,362 & 794 \\
\hline 2020 & 5,685 & 650 & 4,241 & \\
\hline
\end{tabular}

Source: State Statistics Service of Ukraine 2020.

\section{Conceptual approach to the formation of the eco-energy cluster}

An algorithm must be developed to make sound management decisions regarding the transition to renewable energy sources (Fig. 1). In addition, to assess and select the best option for the transformation to a green energy system, the method of hierarchy analysis can be used (T. Saati method), which allows us to quantify the importance of criteria and takes into account the features and influence of external and internal factors on eco-energy cluster structures.

The proposed algorithm can be presented in the following sequence: scientific and methodological aspects of the introduction of energy sources; analysis of key performance indicators; modeling of the energy-saving process with the use of renewable sources based on the method of analysis of hierarchies and economic and mathematical tools; assessment of the efficiency of the 


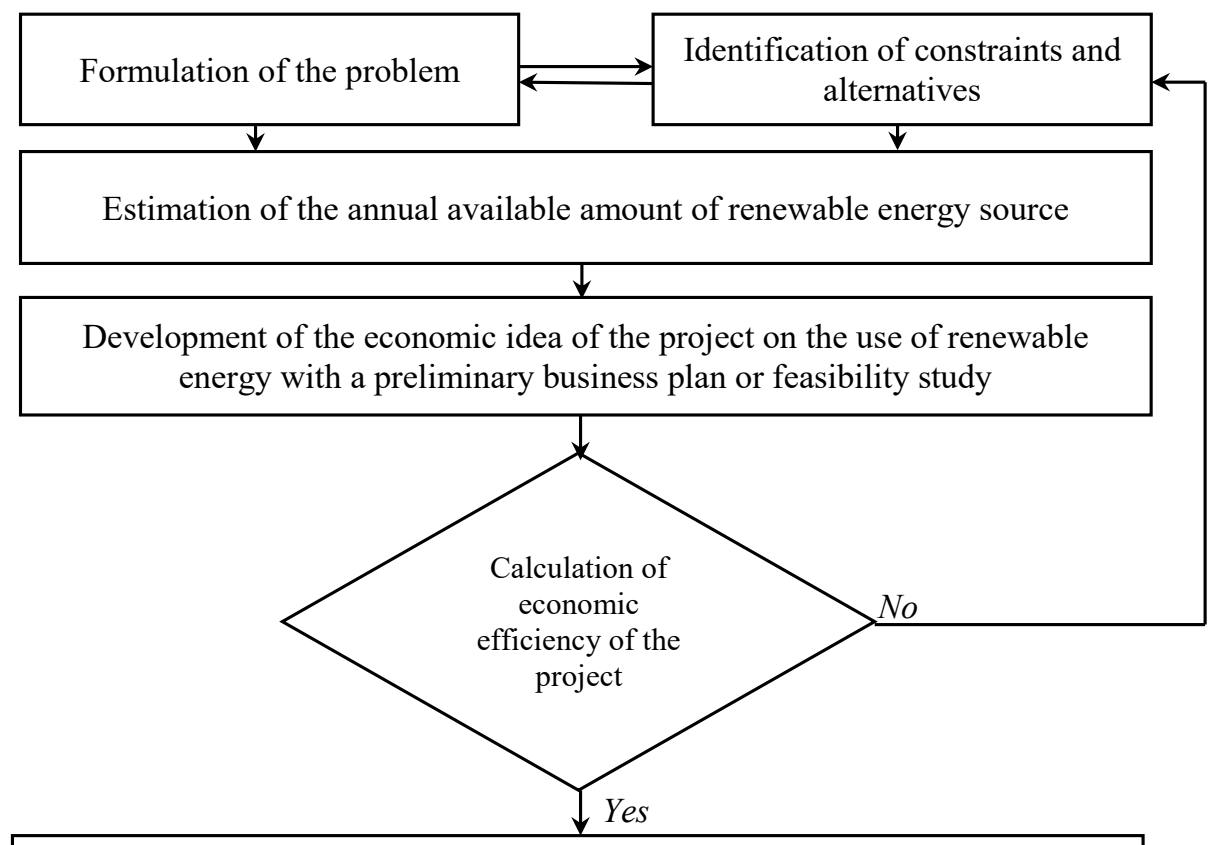

Consultations with project stakeholders - representatives of regional and local authorities, community and business structures - partners

Development of an action plan to ensure the necessary volumes of renewable energy sources

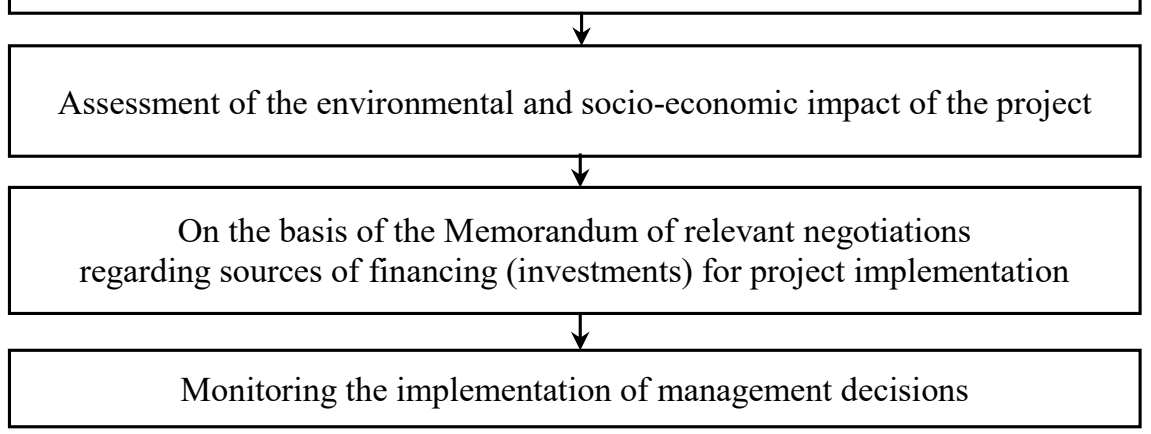

Fig. 1. Algorithm for making management decisions on the transition to renewable energy sources Source: own development

Rys. 1. Algorytm podejmowania decyzji zarządczych dotyczących przejścia na odnawialne źródła energii

transition project; developing a mechanism for financing energy-saving and green technologies and implementing the transition to renewable sources.

The main indicators for calculating the economic efficiency of the project are: the net present value (NPV), which is calculated as the difference between the discounted cash flows of income 
and expenses incurred in the process of implementing investments for the forecast period; Internal Rate of Return (IRR) - the discounted rate at which the present value of net cash flows is equal to the current value of investments in the project; modified internal rate of return (MIRR, $\%)$ - discount rate that equates the future value of cash receipts for the project period; the payback period (PP) - the number of years required for the amount of cash flows from the project to become equal to the amount of initial investment in the project.

In order to modernize the national energy system, it is advisable to develop a concept of creating a cluster (Fig. 2). It complies fully to the EU Clustering Manifesto (Brussels, 2007) as well as the European Cluster Memorandum (Stockholm, 2008), where the basic principles for the cluster policy for the European and international community are understood as the effective operation of economic entities of the respective regions.

The key goal of creating this cluster formation is to reduce logistical costs by modernizing the existing energy infrastructure.

Thus, as a result of research (Nyenno et al. 2020; Ivanov et al. 2019; Kwilinski et al. 2020; Liashenko et al. 2021; Trushkina et al. 2021; Dźwigoł et al. 2021a, 2021b) the conceptual approach to the cluster formation as a specific type of partnership of energy companies, business structures, research institutions, higher education institutions, institutions of logistics, energy and innovation infrastructure, government agencies and authorities are substantiated. Self-government on the basis of green and circular economics, application of the methodology for developing a smart specialization strategy, the introduction of digital technologies and logistics concepts, use of modern financial instruments (venture investment, crowdsourcing, public-private partnership by calling in private investment, credit organizations, pension funds, grants.

This paper proposes a cluster in the energy sector, as significant investment resources are not required to create this structure. This cluster structure can be created in the form of a partnership, which should operate on the principles of equality and the parity of all participants, on the basis of constructive dialogue, the voluntary choice of forms of cooperation, mutual sharing of information and the fulfillment of obligations under economic agreements which are conducted between cluster members.

Most clusters in Ukraine are created as public organizations and public associations; less often - as societies, corporations, associations or utilities.

It should be noted that the differences between the cluster structure and other organizational and legal forms of business associations are as follows: its activities do not determine the special features of government (unlike corporations and concerns); this cluster structure has a permanent nature of activity (unlike consortia); it is created not only for the purpose of constant coordination of economic activity of the enterprises (unlike associations).

According to the Civil Code of Ukraine, the eco-energy cluster can be formed as partnership relations just asregulated legal relations between the participants on the basis of a joint agreement. According to Art. 120 of the Commercial Code of Ukraine, the cluster in the energy sector may have an organizational and legal form as a contractual association of legal entities established to permanently coordinate their economic activities while centralizing one or more management functions. are members of such an association. 


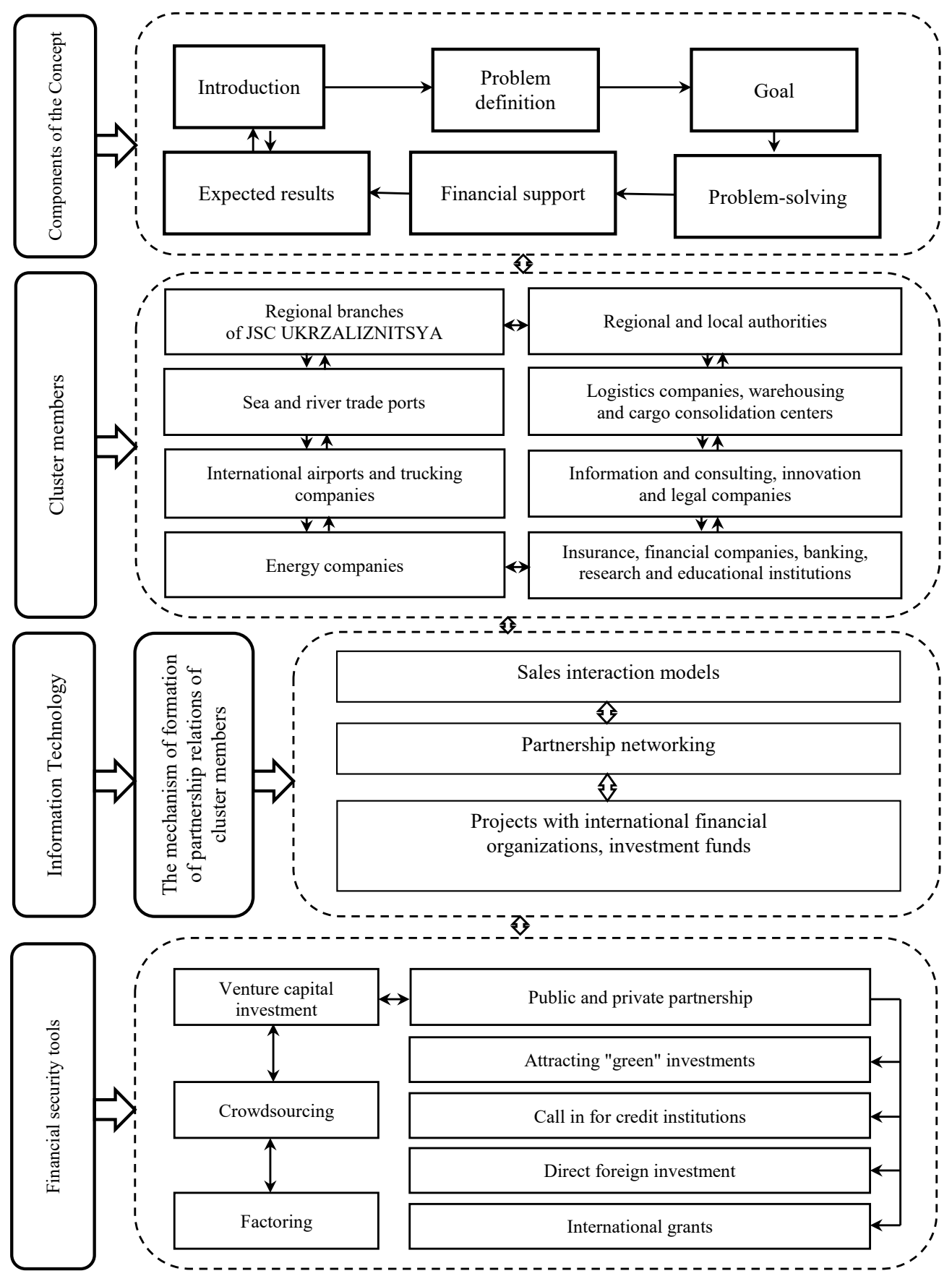

Fig. 2. Formation of eco-energy cluster: conceptual basis Source: own development

Rys. 2. Powstawanie klastra ekoenergetycznego: podstawy koncepcyjne 
In addition, an eco-energy cluster can be created, according to Art. 63 of the Commercial Code of Ukraine, as a communal enterprise operating on the basis of communal property of territorial communities; a joint communal enterprise, which operates on a contractual basis of joint financing by the relevant territorial communities - the subjects of cooperation.

The formation of an eco-energy cluster will help to obtain a synergistic effect, the components of which include:

Economic effect: increasing the level of investment attractiveness of territories; increasing of revenues to budgets (regional, local) due to the formation of a qualitatively new model of regional economy, strengthening of competitive advantages of areas and increasing of economic capacity of territorial communities in the conditions of decentralization; increasing the level of energy and logistics potential; reducing the costs for the organization of logistics activities by reducing the transport component in the cost of services, reducing the time to perform customs procedures for the clearance of goods; ensuring favorable institutional conditions for the functioning of energy and logistics services markets.

Social effect: job creation and employment growth; improving the working conditions of workers in the fields of energy, transport and warehousing.

Environmental effect: reduction of greenhouse gas emissions; reduction of negative impact on the environment from the operation of energy and transport infrastructure; increasing the level of environmental safety.

For the effective functioning of the eco-energy cluster, it is advisable to form an environmentally friendly state energy policy by combining efforts to develop and adopt strategic programs, to obtain expert assistance from international partners and gain financial support for the modernization of the industry.

First, it is recommended to make changes and additions to the Energy Strategy of Ukraine for the period up to 2035, which provides for the confident increase of the use of different sources of renewable energy, which can become one of the tools to ensure industry security.

Secondly, it is advisable to make changes and additions to the concept of creating clusters in Ukraine, to regional development strategies up to 2027 and action plans for implementation from 2021-2023 for the creation of energy cluster structures as a business entity; developing a strategy for the integrated development of the energy sector in Ukraine and the target program "Formation and development of energy clusters in the regions of Ukraine for 2021-2023", which should provide for the creation of cluster structures as a special type of associations in the energy sector, taking into account regional specifics.

Thirdly, it is necessary to introduce a mechanism for financial support for the transformation of the national energy sector using non-traditional sources of funding, including "green" investments. The key instruments of "green" financing of energy modernization in Ukraine, which are effectively used in different countries, include "green" bonds, "green" loans, grants, guarantees, technical assistance, "green" investment funds. For example, the European Bank for Reconstruction and Development and the European Union are moving forward to stimulate green investment and resilience to climate change in the Eastern Partnership countries, including Ukraine. To date, the EBRD has committed $€ 34$ billion to green investments, financing more 
than 1,900 clean technology projects, and reduced hydrocarbon emissions by 102 million tonnes. The EU is providing $€ 61.3$ million in financial assistance to three EBRD stimulus programs. Investments of enterprises in energy efficiency, reduction of carbon footprint, the introduction of advanced modern environmentally friendly technologies, support of waste-free economics, and improvement of the regulatory framework regulating the issues of investing in energy and rational use of resources.

Lastly, it is necessary to develop tools for the implementation of the "green" tariff, the search for effective mechanisms and ways to economically stimulate the construction and operation of renewable energy facilities, taking into account international best practices. This will increase the level of energy, economic and environmental security of Ukraine.

\section{Conclusions and discussion}

Today's realities make it possible to understand that the transition to the sources of renewable energy is a vital factor for the introduction of the energy efficiency policy aimed to increase the macroeconomic efficiency of the country as a whole. The result of the use of alternative energy sources is the obtaining of a synergistic effect (economic, environmental, social).

This can be achieved by: legislative improvement on the area of renewable energy; enhancement of the investment attractiveness of the industry; state support to the providers of "clean" energy for its purchase at fixed tariffs; ensuring the level of energy security of Ukraine through the renovation of the network of existing power plants to increase the level of their reliability and uninterrupted operation; reduction of greenhouse gas emissions from the traditional fuels combustion.

Thus, the most adequate response to the current challenges and threats in Ukraine's energy sector should be balanced structural reforms, which should be aimed at the enlargement of the share of renewable energy sources in the energy balance, the formation of competitive energy markets, the diversification of energy supply, the creation of appropriate institutional conditions for eco-energy cluster structures development, the application of innovative and green technologies. This is in line with the basic provisions of the European Green Deal.

The future lines of research are to develop a regulative system for the support of energy clusters based on international experience for Ukraine. 


\section{References}

BMU 2018. Schulze: GreenTech ist Modernisierungstreiber unserer Wirtschaft. [Online]. https://www. bmu.de/pressemitteilung/schulze-greentech-ist-modernisierungstreiber-unserer-wirtschaft/ [Accessed: 2021-09-01].

Boyle, G. 2012. Renewable Energy: Power for a Sustainable Future. $3^{\text {rd }}$ ed., Oxford University Publication, Oxford, pp. 378-384.

Deloitte 2017. Trends to watch in alternative energy. [Online] https://www2.deloitte.com/ru/en/pages/energy-and-resources/articles/gx-alternative-energy-trends.html [Accessed: 2021-09-01].

Devlin, G. and Bleackley, M. 1988. Strategic Alliances Guidelines for success. Long Range Planning 21(5), pp. 18-23.

Diekman, J. and Traber, T. 2012. Erneuerbare Energien: Quotenmodelle keine Alternative zum EEG. DIW Wochenbericht, 45, pp. 15-20.

Donovan, Ch.W. 2015. Renewable Energy Finance: Powering the Future. Imperial College Business School, London, pp. 132-145.

Dussauge et al. 2000 - Dussauge, P., Garrette, B. and Mitchell, W. 2000. Learning from competing partners: Outcomes and durations of scale and link alliances in Europe, North America and Asia. Strategic Management Journal 21(2), pp. 99-103.

Dźwigol et al. 2021a - Dźwigot, H., Kwilinski, A. and Trushkina, N. 2021a. Green Logistics as a Sustainable Development Concept of Logistics Systems in a Circular Economy. Proceedings of the 37th International Business Information Management Association (IBIMA), 1-2 April 2021 (pp. 10862 10874), Cordoba, Spain: IBIMA Publishing.

Dźwigol et al. 2021b - Dźwigol, H., Trushinina, N. and Kwilinski, A. 2021b. The Organizational and Economic Mechanism of Implementing the Concept of Green Logistics. Virtual Economics 4(2), pp. 74-108, DOI: 10.34021/ ve.2021.04.02(3).

European Environment Agency 2019. Paving the way for a circular economics. Insights on status and potentials. EEA Report No. 11/2019. Publications Office of the European Union. Luxemburg.

Feldman, V. P. and Audretsch, D. B. 1999. Innovation in Cities: Science based Diversity. Specialization and Localized Competition - European Economic Review 43, pp. 409-429.

FeSER, E.J. 1998. Old and New Theories of Industry Clusters. London: SelectedWorks.

Fox, B. and Flynn, D. 2014. Wind Power Integration: Connection and System operational aspects. The Institution of Engineering and Technology, London.

Henning, H.-M. 2015. Phases of transformation of the energy system (Phasen der Transformation des Energiesystems). Energiewirtschaftliche Tagesfragen 1(2), pp. 10-13 (in German).

Ivanov et al. 2019 - Ivanov, S., Dźwigol, H. and Trushrina, N. 2019. Proposals for the Formation of a Transport and Logistics Cluster as an Institution of Regional Development (on the Example of Donetsk Economic Region). Economic Herald of the Donbas 4(58), pp. 51-60, DOI: 10.12958/18173772-2019-4(58)-51-60.

Kwilinski et al. 2020 - Kwilinski, A., Zaloznova, Yu., Trushinina, N. and Rynkevych, N. 2020. Organizational and methodological support for Ukrainian coal enterprises marketing activity improvement. E3S Web of Conferences 168, Article 00031, DOI: 10/1051/ e3sconf/202016800031.

Liashenko et al. 2021 - Liashenko, V., Ivanov, S. and Trushrina, N. 2021. A Conceptual Approach to Forming a Transport and Logistics Cluster as a Component of the Region's Innovative Infrastructure (on the Example of Prydniprovsky Economic Region of Ukraine). Virtual Economics 4(1), pp. 19-53, DOI: 10.34021/ve.2021.04.01(2). 
MeIER, P. and VAGLiasindi, M. 2015. World Bank Group. The design and sustainability of renewable energy incentives: An economic analysis (Directions in development), IBRR, the World Bank, Washington, pp. $220-230$.

Nate et al. 2021 - Nate, S., Bilan, Y., Cherevatskyi, D., Kharlamova, G., Lyakh, O. and Wosiak, A. 2021. The Impact of Energy Consumption on the Three Pillars of Sustainable Development. Energies 14, 1372, DOI: 10.3390/en14051372.

Nyenno et al. 2020 - Nyenno, I., Selivanova, N., Korolenko, N. and Truba, V. 2020. The energy policy risk management system model: theories and practices. Polityka Energetyczna - Energy Policy Journal 23(4), pp. 33-48, DOI: 10.33223/epj/127699.

PorTER, M.E. 1998. Clusters and New Economics of Competition. Harward Business Review, NovemberDecember, pp. 77-90.

RutKo, D. 2016. Foreign experience in the development of innovative clusters. Science and Innovation 1(155), pp. 18-22.

SERdyuk, O.S. and Trushina, N.V. 2017a. Regarding the prospects for the development of the thermal energy sector in the context of environmental policy. Economics and society 12, pp. 449-453.

SerdyuK, O.S. and TrushKinA, N.V. 2017b. Regarding the prospects for the development of renewable energy in Ukraine. Economics of the enterprise: modern problems of theory and practice: materials of the sixth International Scientific-Practical Conference (Odessa, September 22-23, 2017). Odessa: Atlant, pp. 262-264.

Serdyuk, O.S. and Trushrina, N.V. 2017c. Regarding the development of renewable energy in the context of the Energy Strategy of Ukraine. World scientific extent: collection of scientific articles. Agenda Publishing House, Coventry, United Kingdom, pp. 17-21.

State Statistics Service of Ukraine 2020. 'Energy consumption from renewable sources for 2007-2019. Kyiv.

Swann, G.M.P. and Preveser, M.A. 1996. Comparison of the Dynamics of Industrial Clustering in Computing and Biotechnology. Research Policy 25(7), pp. 1139-1157.

Terrados et al. 2009 - Terrados, J., Almonacid, G. and Perez-Higueras, P. 2009. Proposal for a combined methodology for renewable energy planning. Application to a Spanish region. Renewable and Sustainable Energy Reviews 13, pp. 2022-2030.

TRIEB, F. 2013. Integration erneuerbarer Energiequellen bei hohen Anteilen an der Stromversorgung. Energiewirtschaftliche Tagesfragen 7, pp. 28-32.

Trushrina et al. 2021 - Trushrina, N., Dźwigol, H. and Kwilinski, A. 2021. Cluster Model of Organizing Logistics in the Region (on the Example of the Economic District "Podillya"). Journal of European Economics 20(1), pp. 127-145, DOI: 10.35774/jee2021.01.127.

World Energy Outlook 2020. The future of world energy during a pandemic COVID-19. [Online] http:// uwea.com.ua/ua/news/entry/ [Accessed: 2021-09-03].

XAVIER, Y.M. de A. 2015. Energy Law in Brazil: oil, gas and biofuels. Springer International Publishing, Switzerland.

YuAn et al. 2014 - YuAn, J., Luo, G. and Chen, J. 2014. Renewable energy in China. North China Electric Power University, Beijing. 


\title{
Koncepcje transformacji krajowego systemu energetycznego Ukrainy w kontekście Europejskiego Zielonego Ładu
}

\begin{abstract}
Streszczenie
Celem artykułu jest naukowe i metodologiczne uzasadnienie koncepcji dotyczących przekształcenia krajowego systemu energetycznego Ukrainy poprzez tworzenie klastrów ekoenergetycznych. Analizie poddano międzynarodowe raporty dotyczące rozwoju zielonej energii w różnych krajach. Przeprowadzano analizę dynamiki zużycia energii na Ukrainie w oparciu o źródła odnawialne w latach 2007-2019. Zaproponowano algorytm podejmowania decyzji zarządczych dotyczących przejścia na odnawialne źródła energii. W celu przekształcenia krajowego systemu energetycznego uzasadniona jest koncepcja tworzenia klastra ekoenergetycznego jako elementu infrastruktury innowacyjnej opartej na inteligentnej specjalizacji. Wykazano, że struktura ta powinna mieć formę partnerstwa firm energetycznych, struktur biznesowych, instytucji badawczych, uczelni wyższych, instytucji infrastruktury logistycznej, energetycznej i innowacyjnej oraz agencji rządowych. To z kolei zapewni efekt synergiczny (ekonomiczny, środowiskowy, społeczny) poprzez poprawę szeregu istniejących przepisów dotyczących alternatywnych źródeł energii, co zwiększy efektywność ekonomiczną ich produkcji takich jak: rozwój projektów inwestycyjnych w celu przyciągnięcia dodatkowych inwestycje w tej branży; gwarancje państwa dla producentów „czystej” energii na jej zakup po stałych taryfach; zapewnienie poziomu bezpieczeństwa energetycznego Ukrainy poprzez modernizację sieci istniejących elektrowni w celu podniesienia poziomu ich niezawodności i nieprzerwanej pracy; ograniczenie emisji gazów cieplarnianych ze spalania paliw tradycyjnych.
\end{abstract}

SŁOWA KLUCZOWE: polityka energetyczna państwa, krajowy system energetyczny, energia odnawialna, klaster ekoenergetyczny, zielone technologie, zielona ekonomia 